\title{
WIEK OSADÓW MIĘDZYGLINOWYCH NA LEWYM BRZEGU WARTY W POZNANIU W ŚWIETLE BADAŃ PALINOLOGICZNYCH
}

\author{
KRYSTYNA MILECKA ${ }^{1}$, MARCIN NYĆKOWIAK ${ }^{2}$, MACIEJ TROĆ 2 \\ ${ }^{1}$ Instytut Paleogeografii i Geoekologii, Uniwersytet im. Adama Mickiewicza w Poznaniu, \\ ${ }^{2}$ GT Projekt, Swadzim
}

\begin{abstract}
The main aim of this article was to estimate the time of accumulation of organic sediments from Eemian interglacial, found in inter-clay layers. Palynological analysis was done for the samples of sediments. They were taken within the area of Poznań at the sites of geotechnical and geological research. Rebuilding of city-stadium in Bułgarska street was a good opportunity to core the organic sediments interlying the morainic clays which were accumulated during the Mazovian and Vistulian glaciation. Layers lying between the clays contain organic material very often and this was the case this time. Palynological analysis revealed accumulation of these organic sediments during the 5th and 6th period of Eemian Interglacial according to the biostratygraphical classification of Tobolski (1991).
\end{abstract}

Keywords: Poznań, interclay deposits, palynology

\section{WSTĘP}

Na terenie miasta Poznania w obrębie utworów międzyglinowych występują osady pochodzenia organicznego. W czasie badań geotechnicznych lub geologiczno-inżynierskich wykonywanych przy ul.: Murawa, Opłotki, Rydlewskich oraz przy stadionie piłkarskim na ul. Bułgarskiej pobrano próbki tych osadów w celu wykonania analiz palinologicznych. Pozwalają one, w zestawieniu z wynikami badań dla podobnych stanowisk w Winiarach, Głównej i Szelagu, na pełniejsze określenie pozycji stratygraficznej osadów międzyglinowych i glin morenowych na terenie Poznania oraz okolic. Prezentowane wyniki są również wkładem w poznanie zasięgu występowania osadów interglacjału eemskiego $\mathrm{w}$ analizowanym rejonie.

\section{TEREN BADAŃ ORAZ SZKIC GEOMORFOLOGICZNY}

Teren badań obejmuje lewy brzeg Warty miasta Poznań. W granicach administracyjnych miasta i jego najbliższych okolicach można wyróżnić następujące elementy geomorfologiczne: 
- strefa moren czołowych; stanowią część główną ciagu czołowomorenowego stadiału poznańskiego, podstawowymi elementami reprezentującymi strefę moren czołowych na północy Poznania są Góra Morasko i Góra Dziewicza;

- równiny dennomorenowe; są dominującą formą geomorfologiczną, gdzie w granicach miasta Poznań występuje wysoczyzna morenowa typu płaskiego o wysokościach względnych sięgających od 2 do $5 \mathrm{~m}$ i spadkach do $2^{\circ}$; według Bartkowskiego (1957) w południowej części miasta zalega na wysokościach 80-85 m n.p.m. (poziom A), a w części północnej u podnóża moreny czołowej Moraska na wysokości 90-100 m n.p.m. (poziom B);

- równiny sandrowe współbudujące równiny dennomorenowe zbudowane z piasków wodnolodowcowych; Biedrowski (1968), opierając się na istniejącej literaturze i własnych badaniach w rejonie Poznania, wyróżnił następujące sandry: Lusowski, Junikowski, Strzeszyński, Piątkowski, Naramowicki, Kiciński i Głównej. Formy te powstały na przedpolu lądolodu zlodowacenia północnopolskiego fazy poznańskiej;

- rynny i doliny rozcinające równiny dennomorenowe; główne osie morfologiczne w rejonie Poznania to: dolina Warty o przebiegu północ-południe oraz rynny subglacjalne Cybiny-Bogdanki i Strumienia Junikowskiego; rynny te są dużymi formami o szerokości $0,5 \mathrm{~km}$ i głębokości 20-30 m, wypełnione przez osady plejstoceńskie (zastoiskowe i korytowe), a powyżej przez holoceńskie, w tym pochodzenia roślinnego (torfy, namuły);

- terasy akumulacyjno-erozyjne rozmieszczone wzdłuż Warty, Bartkowski (1957) wydzielił siedem teras;

- równiny zastoiskowe, są to przeważnie pozytywne formy terenu zbudowane $\mathrm{z}$ osadów zastoiskowych i powstałe w szczelinach lodowca, do najważniejszych wzniesień należą wzgórza Św. Wojciecha, Góra Przemysława oraz rejon dworca autobusowego na Śródce.

Otwory badawcze wykonano na terenie wysoczyzny morenowej nazwanej przez Deję (1969) Wysoczyzną Jeżycką (obszar położony między ul. Dąbrowskiego i rynną Strumienia Junikowskiego a przełomowym odcinkiem doliny Warty) oraz Wysoczyzną Winiarską (na północ od doliny Bogdanki).

W podziale geomorfologicznym zaprezentowanym przez Kondrackiego (1998) analizowana część miasta położona jest na Pojezierzu Poznańskim, granicząc od wschodu z Poznańskim Przełomem Warty.

\section{LOKALIZACJA STANOWISK I METODY BADAŃ}

Otwory badawcze zostały odwiercone w czasie badań geotechnicznych oraz geologiczno-inżynierskich na potrzeby budowy lub rozbudowy istniejących obiektów. Najpełniejszy profil osadów organicznych został pobra- 
ny i przebadany z otworu nr $1 \mathrm{z}$ rejonu ul. Bułgarskiej. Z pozostałych punktów pobrano pojedyncze próbki (nr 2 ul. Rydlewskich, $\mathrm{nr} 3$ ul. Murawa, nr 4 ul. Opłotki).

Do badań palinologicznych pobierano próby o objętości około $2-3 \mathrm{~cm}^{3}$ i poddawano je standardowej obróbce laboratoryjnej (Berglund, Ralska-Jasiewiczowa 1986). Jej podstawowym celem było usunięcie mineralnych części osadu, które utrudniaja, a często uniemożliwiają wykonanie preparatu mikroskopowego. Pozostałą część osadu poddano maceracji za pomocą mieszaniny bezwodnika kwasu octowego i stężonego kwasu siarkowego w proporcji 9:1. Tak przygotowany materiał przepłukiwano w kwasie octowym i wodzie destylowanej, a następnie zatopiono w glicerynie, co umożliwia wieloletnie przechowanie prób palinologicznych w laboratorium Zakładu Biogeografii i Paleoekologii w celach porównawczych. Właściwa analiza palinologiczna obejmowała jakościową i ilościową identyfikację sporomorf znajdujących się w preparacie mikroskopowym. Do zliczania stosowano powiększenie 400x.

Niestety, ze względu na niską frekwencję ziaren pyłku w analizowanych próbach nie w każdym przypadku było możliwe dotrzymanie zasady zliczania minimalnej liczby 500 sporomorf, która pozwala na statystyczne porównanie otrzymanych wyników. Fakt ten spowodowany był wysokim udziałem substancji mineralnej w badanych warstwach osadów rzecznych oraz często złym stanem zachowania pyłku. W próbach starano się oznaczyć 300-400 sporomorf, każdorazowo liczono co najmniej jeden pełny preparat o powierzchni $400 \mathrm{~mm}^{2}$. W przypadku prób o niskiej frekwencji liczono dwa preparaty. Najniższą frekwencją charakteryzowały się osady ze stanowiska przy ul. Opłotki (Komorniki), gdzie suma ziaren pyłku drzew, krzewów i roślin zielnych (AP + NAP $=100 \%$, tzw. suma kalkulacyjna) wyniosła 128 ziaren. Uzyskane wyniki wszystkich prób przeliczono na procentowy udział w stosunku do zdefiniowanej sumy kalkulacyjnej.

Na podstawie ilościowego i jakościowego składu poszczególnych spektrów pyłkowych przeprowadzono wnioskowanie dotyczące czasu ich akumulacji.

\section{CHARAKTERYSTYKA GEOLOGICZNA ANALIZOWANEGO TERENU}

W przekroju geologicznym w regionie Wielkopolski wyróżnić można trzy różne zespoły skalne (Grocholski 1991):

1. skały wieku przedpermskiego, które zostały sfałdowane, z okresu ruchów górotwórczych orogenezy waryscyjskiej;

2. skały mezozoiczne ze skałami młodszego permu; osady te są nachylone zgodnie w kierunku północnym lub północno-wschodnim, tworząc tzw. monoklinę zaburzoną lokalnie wysadami soli cechsztyńskiej i formami dysloka- 
cji nieciagłej w postaci uskoków, które sprzyjają tworzeniu zrębów i rowów tektonicznych;

3. utwory kenozoiczne - warstwy najmłodsze zalegające prawie poziomo.

Rejon Poznania leży na granicy dwóch jednostek geologiczno-tektonicznych: monokliny przedsudeckiej i synklinorium szczecińsko-łódzko-miechowskiego (Pożarski 1974). Istotną formą geologiczno-strukturalną występującą w rejonie Poznania jest rów tektoniczny Poznań-Gostyń. Jest to paleogeńsko-neogeńska paleostruktura ciągnąca się od Poznania po Gostyń (Ciuk 1978). Strukturę tą wypełniają głównie osady neogeńskie z grubymi pokładami węgli brunatnych (Ciuk 1965). Na lewym brzegu Warty przeprowadzono głęboki otwór poszukiwawczy: GN-1 Ławica (głębokość końcowa - 3652 m). Litologię i stratygrafię otworu IG-1 Ławica przedstawiono na rycinie 1, gdzie opis sedymentologiczny przedstawiono za Grocholskim (1991).

W prezentowanym profilu osady górnego mezozoiku zostały określone jako kredy górnej, co jest zgodne $\mathrm{z}$ opisem przedstawionym w Katalogu wierceń przebijajacych utwory kenozoiku, Wydawnictwa Geologiczne, Warszawa 1971, oraz według Grocholskiego (1991). Natomiast według Dadleza i współpracowników, (2000) oraz Jaskowiak-Schoeneichowa (1979) utwory te można zakwalifikować do górnej jury.

$\mathrm{Na}$ podłożu mezozoicznym zostały odłożone osady trzeciorzędowe. Osady trzeciorzędowe Wielkopolski złożone są z utworów: eocenu górnego, oligocenu, miocenu i pliocenu (Ciuk 1978). Reprezentuja je osady morskie, brakiczne i lądowe. Pierwsze przeważają głównie w paleogenie, drugie w neogenie (Odrzywolska-Bieńkowa i in. 1979). Utwory trzeciorzędowe zachodniej części Niżu Polskiego, w skład którego wchodzi Wielkopolska, rozwinęły się w obrębie rozległego, epikontynentalnego basenu sedymentacyjnego, ciagnącego się od Morza Północnego przez Niemcy i Polskę po Białoruś (Piwocki 2002). Akumulację osadów neogeńskich, na analizowanym terenie, kończą iły serii/formacji poznańskiej barwy pstrej lub zielononiebieskiej o stropie na rzędnej około 20-60 m n.p.m.

Osady plejstoceńskie i holoceńskie występują w przypowierzchniowej budowie geologicznej na całym analizowanym terenie. Do utworów wieku plejstoceńskiego zaliczyć można osady: bezpośredniej akumulacji zlodowaceń południowopolskich, środkowopolskich, międzyglinowe, bezpośredniej akumulacji zlodowaceń północnopolskich, zastoiskowe powstałe pomiędzy fazą leszczyńską i poznańską oraz fluwioglacjalne fazy poznańskiej spoczywające na glinach zwałowych zlodowaceń północnopolskich.

$\mathrm{Na}$ obszarach wysoczyznowych bezpośrednio na stropie iłów trzeciorzędowych zalega pakiet glin zlodowaceń południowopolskich i środkowopolskich. Gliny najstarszych zlodowaceń wypełniają obniżenia podłoża podczwartorzędowego. Na najstarszych glinach odłożone są gliny morenowe zlodowaceń środkowopolskich: zlodowacenia Odry i Warty. Przeważnie utwory z tych dwóch 


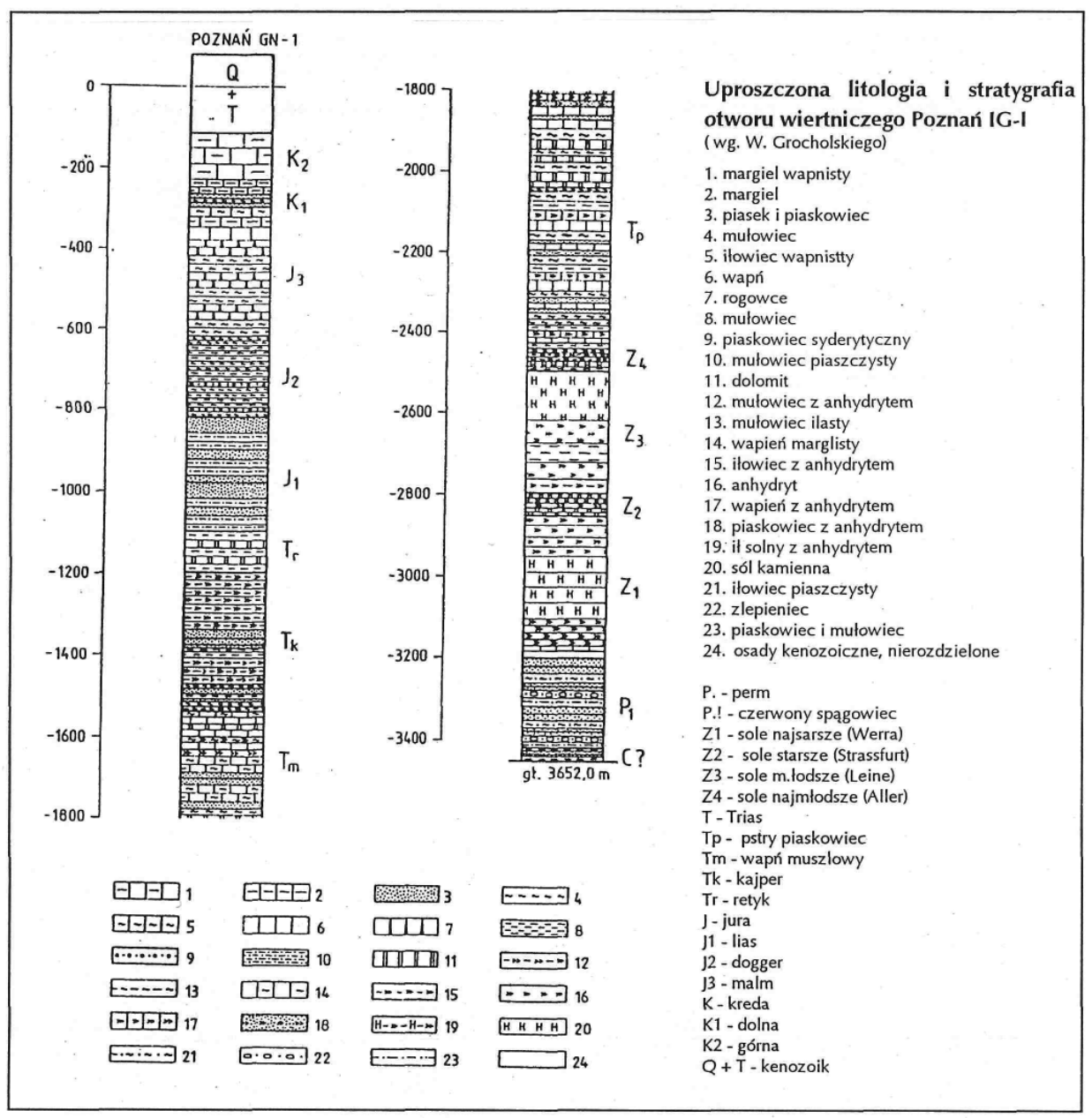

Ryc. 1. Litologia i stratygrafia otworu GN-1

Fig. 1. Lithology and stratigraphy of core GN-1

zlodowaceń tworzą wspólny pakiet, ale również mogą być rozdzielone piaskami wodnolodowcowymi. Osady zlodowacenia warty to przede wszystkim sedymentacja glin morenowych o miąższości do $30 \mathrm{~m}$. Sedymentację okresu zlodowaceń środkowopolskich kończą piaski i żwiry wodnolodowcowe (Chmal 1997) o lokalnym rozpowszechnieniu. Osady międzyglinowe to przede wszystkim utwory interglacjału eemskiego. W okresie tym nastąpiła erozja wcześniejszych osadów. Utwory interglacjału eemskiego to utwory jeziorne: gytie, torfy i mułki zastoiskowe oraz osady piaszczyste przeważnie drobnoziarniste. Do osadów organogenicznych zaliczyć należy również szczątki drewna (Chmal 1997). Orientacyjny zasięg utworów międzyglinowych za Dąbrowskim (1999) opisano na rycinie 2. 


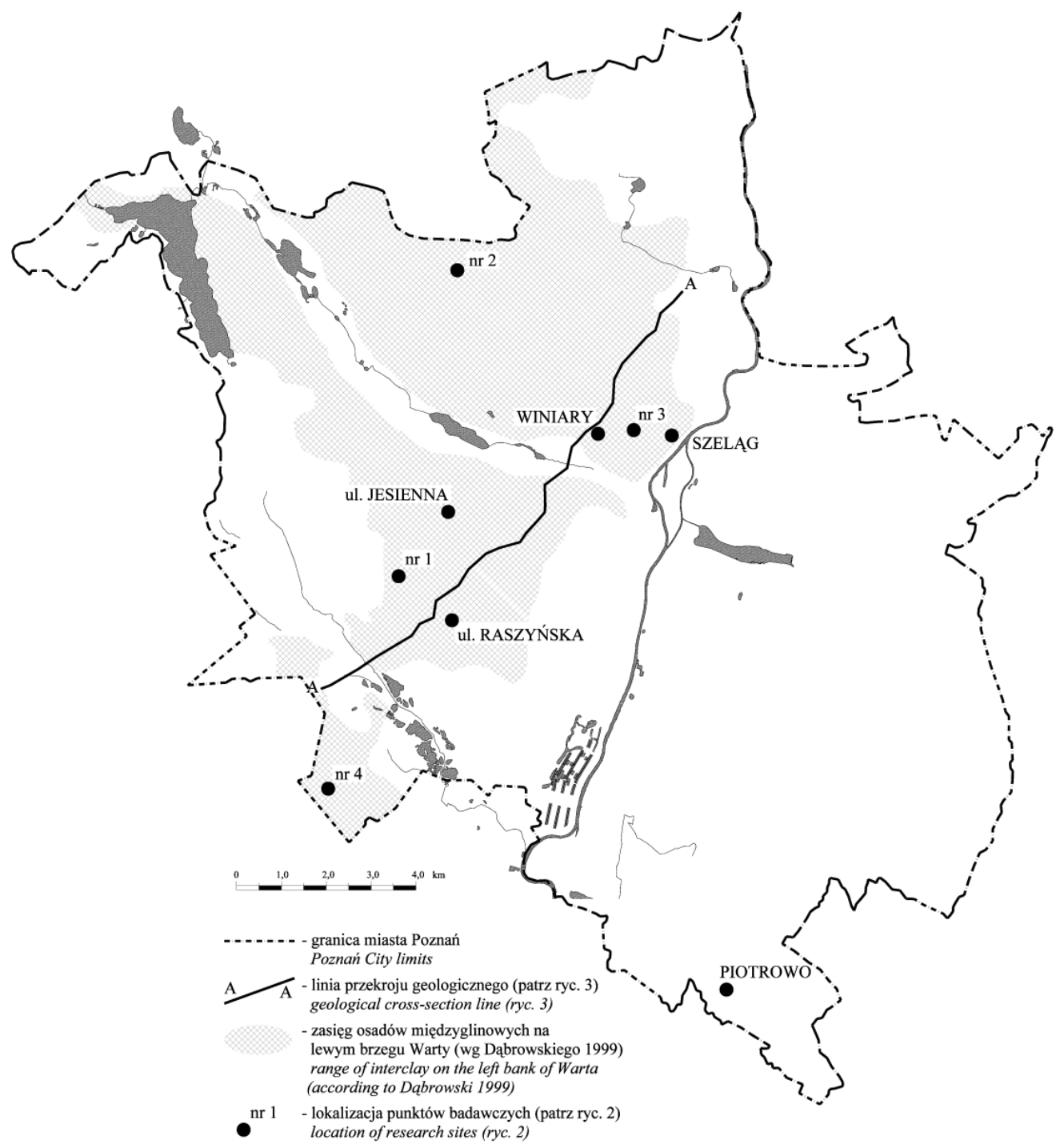

Ryc. 2. Mapa dokumentacyjna, położenie stanowisk omawianych badań

Fig. 2. Location of the discussed research sites

Wkroczenie ostatniego lądolodu na analizowany obszar zapisane zostało w pierwszej kolejności sedymentacją mułków piaszczystych zastoiskowych (Chmal 1997). Mułki zastoiskowe występują lokalnie, większym rozprzestrzenieniem charakteryzują się piaski i żwiry wodnolodowcowe dolne pochodzące $\mathrm{z}$ transgresji lądolodu fazy leszczyńskiej. Piaski i mułki mogą również pochodzić z interglacjału eemskiego. Glina morenowa fazy leszczyńskiej ma miąższość kilkumetrową, rzadko przekracza $10 \mathrm{~m}$ i jest silnie spiaszczona. 
Odmienna budowa geologiczna występuje w rejonach dolin rzecznych, na przykład Bogdanki czy Strumienia Junikowskiego. Doliny te głęboko wcinają się w podłoże do stropu glin morenowych zlodowacenia środkowopolskiego lub stropu iłów (w przypadku doliny Bogdanki nawet głębiej) i wypełnione są osadami zastoiskowymi odłożonymi głównie w okresie pomiędzy fazą leszczyńską i fazą poznańską. Osady zastoiskowe przykryte zostały utworami wodnolodowcowymi, w które wcięły się holoceńskie cieki, w wyniku czego odłożone zostały głównie grunty organiczne.

W fazie poznańskiej w czasie stacjonowania lądolodu na północ od Poznania, na linii Góra Moraska i Dziewicza, nastąpiło kształtowanie sandrów tego rejonu. Północną, marginalną strefę odwodnienia lądolodu wyznacza ciąg pagórków moreny czołowej fazy poznańskiej zlodowacenia północnopolskiego, których wiek określa Kozarski (1995) na około 18400 lat BP. W rejonie Poznania Biedrowski (1968) opisał następujące sandry: Lusowski, Junikowski, Strzeszyński, Piątkowski, Naramowicki, Kiciński i Głównej. Na lewym brzegu Warty w obrębie miasta Poznań występują osady wodnolodowcowe (piaski drobne, średnie, rzadziej grubsze) sandrów Junikowskiego, Strzeszyńskiego i Piątkowskiego o miąższości do kilku metrów.

Do osadów uformowanych w holocenie należą osady aluwialne wypełniające doliny rzeczne wykształcone w facji korytowej, pozakorytowe (rozlewiskowe, zastoiskowe) i starorzeczy (bagiennej - organicznej). Odmienną kategorię gruntów stanowią utwory pochodzenia antropogenicznego, tzw. kulturowe, związane z działalnością ludzką na przestrzeni wieków.

Na rycinie 3 przedstawiono poglądowy przekrój geologiczny plejstocenu lewobrzeżnego Poznania, natomiast na rycinie 4 przebieg tego przekroju.

\section{WYNIKI BADAŃ PALINOLOGICZNYCH NA TLE WYNIKÓW WCZEŚNIEJSZYCH BADAŃ GRUNTÓW ORGANICZNYCH STANOWISK INTERGLACJAŁU EEMSKIGO}

Badania palinologiczne omawianych osadów organicznych wskazują na ich akumulację podczas ciepłych okresów interglacjalnych. Wszystkie analizowane spektra cechuje leśny charakter odzwierciedlonej roślinności z dominacją zbiorowisk liściastych zrzucających liście na zimę lub lasów iglastych z dominacją sosny i świerka. Wśród taksonów leśnych najwyższą frekwencję na stanowiskach ul. Murawa, ul. Rydlewskich oraz ul. Opłotki wykazały ziarna pyłku leszczyny i grabu oraz olszy. Mniej liczebnie występował pyłek: dębu, lipy, wiązu i jesionu. Osady ze stadionu na ul. Bułgarskiej cechowała najwyższa procentowa zawartość ziaren pyłku sosny i brzozy, a następnie grabu i pozostałych drzew mezofilnych (ryc. 5). Wyraźnie zaznacza się też udział świerka. Ogólnie w próbach jest bardzo niewiele ziaren pyłku roślin zielnych. Są to głównie: 


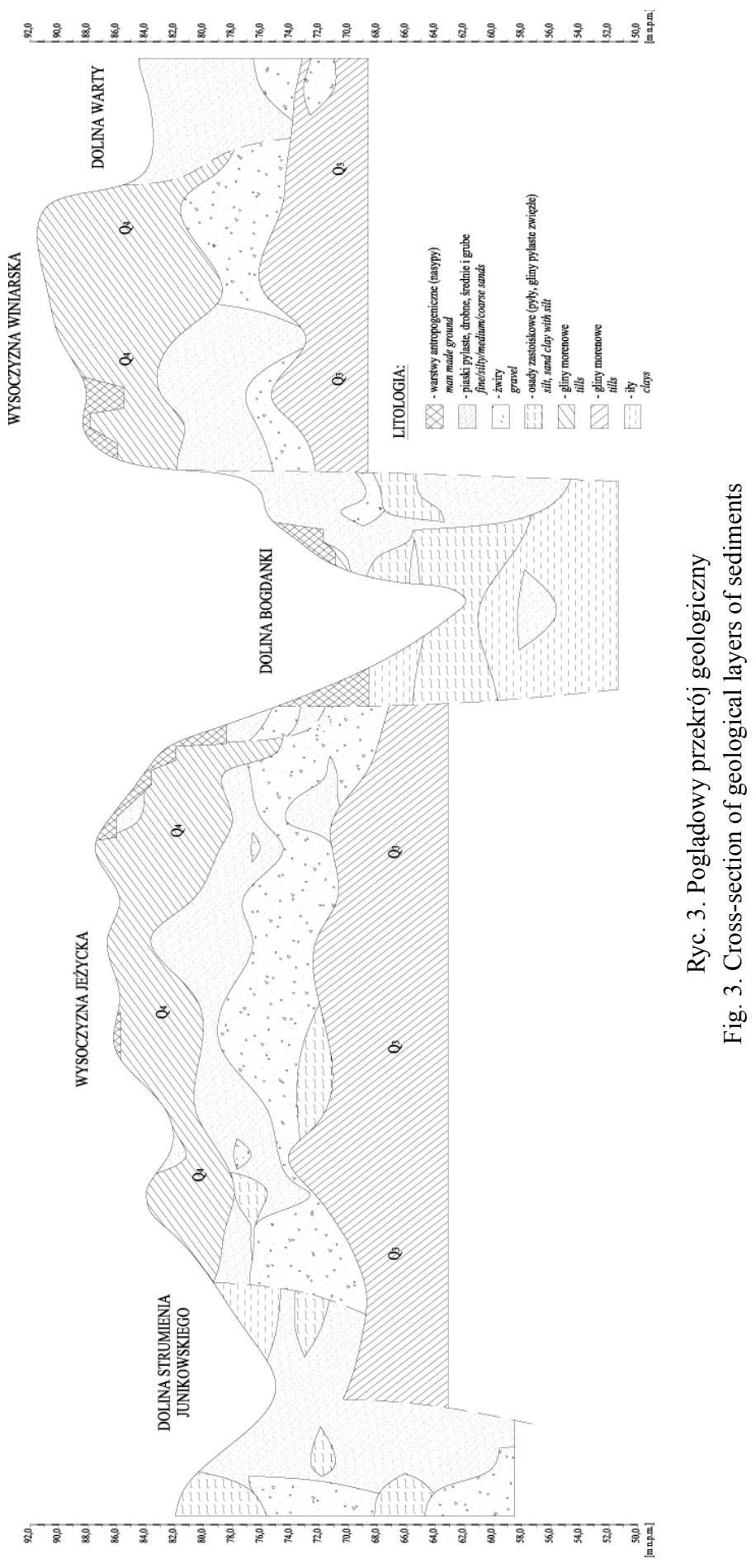



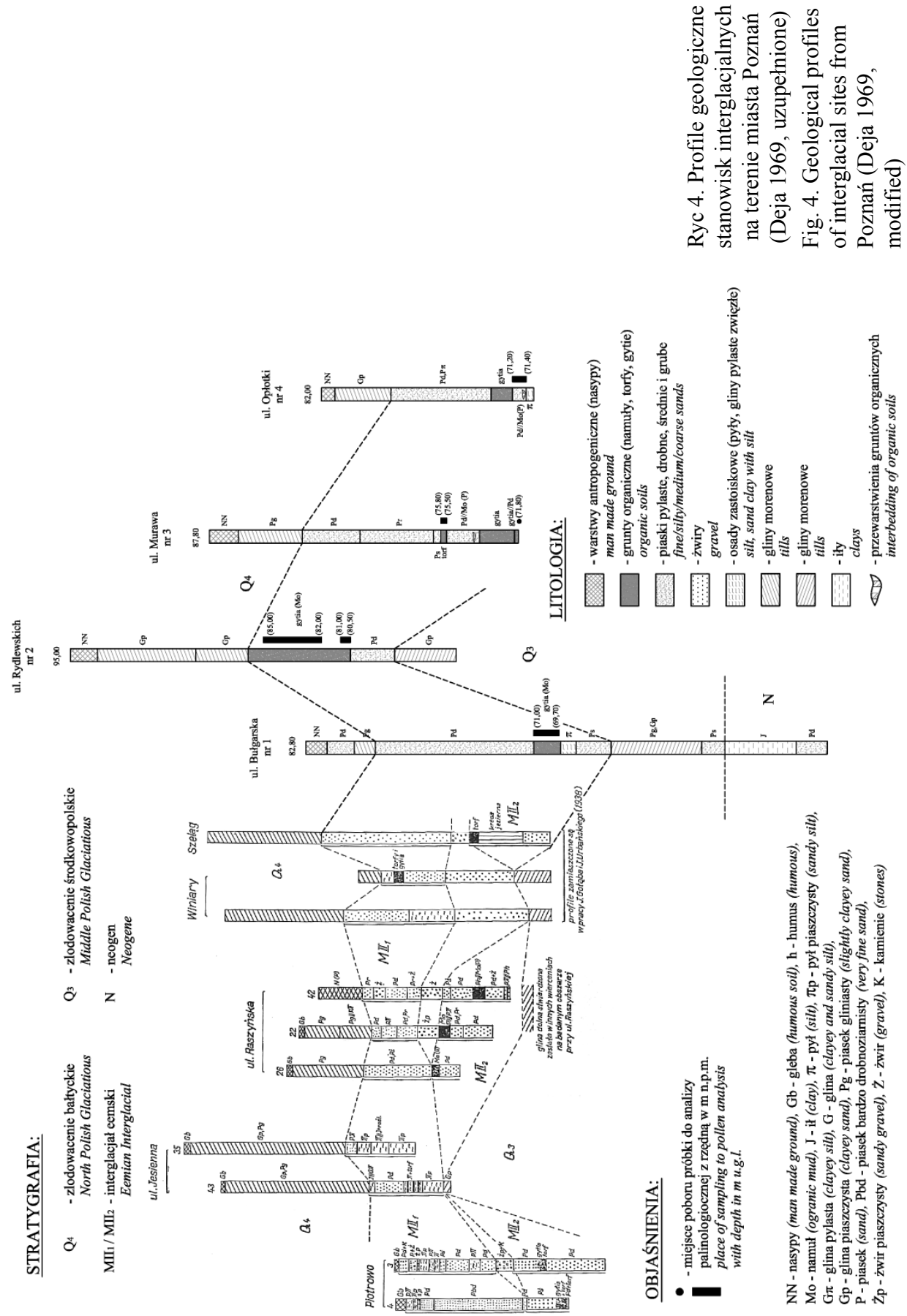

案




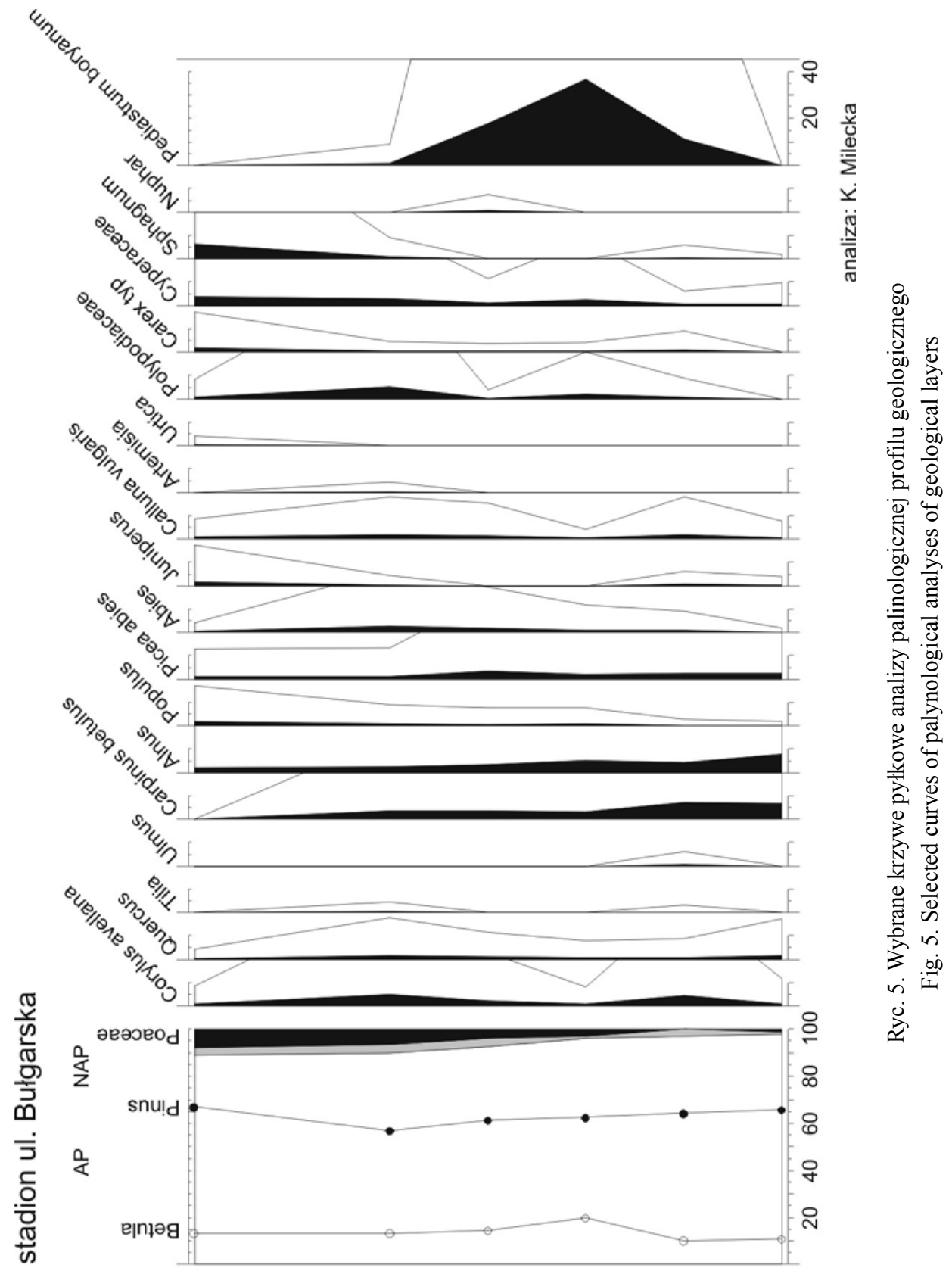

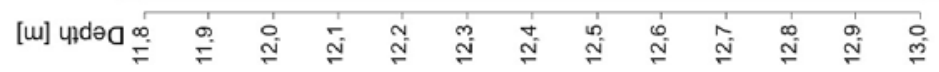


trawy (Poaceae), bylica (Artemisia sp.), szczaw (Rumex acetosa/acetosella typ), pokrzywa (Urtica sp.) i kilka innych występujących pojedynczo. W grupie sporomorf klasyfikowanych jako składniki lokalnych zbiorowisk roślinnych stwierdzono najwięcej pyłku turzycowatych (Carex typ, Cyperaceae) oraz zarodniki paproci (monolete fern spores) i skrzypów (Equisetum sp.). Praktycznie nie występowały ziarna pyłku roślin wodnych, z wyjątkiem nielicznych cenobiów Pediastrum, należących do grupy zielenic, składników planktonu jeziornego. Ich obecności jednak nie należy łączyć z wodnym środowiskiem akumulacji osadów organicznych, gdyż pojedyncze występowanie tych glonów może być następstwem okresowego zalewu terenów wilgotnych, związanego na przykład $\mathrm{z}$ wiosennymi roztopami. W kilku spektrach występują pojedyncze ziarna jemioły (Viscum sp.) i bluszczu (Hedera helix).

Charakterystyczną cechą łączącą wszystkie analizowane spektra, z wyjątkiem ul. Bułgarskiej, był ponadto niski udział sosny oraz to, że w żadnym z nich nie stwierdzono ziaren pyłku buka (Fagus sylvatica).

Tak syntetycznie przedstawione rezultaty analizy pyłkowej zestawiono z wynikami wcześniej wykonywanych badań paleobotanicznych na terenie Poznania i Wielkopolski (Gołąb, Urbański 1938; Sawicki 1954; Środoń 1956; Deja 1969; Tobolski 1991). Stanowiska, które analizowano, były publikowane już nawet w okresie przedwojennym, co świadczy o długiej tradycji zainteresowań związanych z problematyką geologiczną okolic Poznania.

Uzyskane wyniki posiadają cechy wyróżniające dla interglacjału eemskiego, zdefiniowane przez Mamakową (2003) w syntetycznym opracowaniu zagadnień palinostratygraficznych w Polsce. Należą do nich m.in.:

1. Wysoki udział leszczyny, sięgający $80 \%$, niespotykany w innych interglacjałach. W analizowanych osadach udział Corylus avellana nie był tak wysoki i wynosił, na ogól, poniżej 50\%, ale i tak jest wyróżniający.

2. Wysoki udział świerka i jodły w młodszej części interglacjału. W niektórych analizowanych próbach osadów udział świerka sięga około 10\%. Biorąc pod uwagę słabą zdolność rozprzestrzeniania ziaren pyłku Picea abies i jego podreprezentatywność w diagramach pyłkowych, jest to wartość znaczna.

Do pozostałych cech określających czas akumulacji analizowanych osadów na interglacjał eemski zaliczamy:

1. Niski udział ziaren pyłku sosny podczas optimum klimatycznego Eemu. To cecha bardzo charakterystyczna ze względu na dużą siłę pylenia Pinus sylvestris i jej wyraźną nadreprezentację w diagramach pyłkowych.

2. Brak buka, który nie występuje w sukcesji interglacjału eemskiego i nie został stwierdzony w żadnym spektrum badanego materiału.

W świetle otrzymanych wyników oraz charakterystyki sukcesji roślinnej interglacjału eemskiego przedstawionej przez Tobolskiego (1991) oraz Mamakową 
(2003) czas akumulacji warstw osadów organicznych z wierceń przy ul. Murawa, ul. Rydlewskich oraz ul. Opłotki można określić na poziom 5 „CARPINUS” (Tobolski 1991), który w interpretacji Mamakowej (2003) jest zdefiniowany jako E5 „CARPINUS-CORYLUS-ALNUS”. Ten regionalny poziom pyłkowy jest ostatnim zaliczanym do środkowego Eemu, czyli najlepszych termicznie warunków rozwoju roślinności. Zarówno na stanowiskach wzorcowych z rejonu Konina (Tobolski 1991), Zgierza-Rudunki (Jastrzębska-Mamełka 1985), Horoszki (Granoszewski 2003) i innych, oraz $w$ omawianych materiałach $w$ tej fazie stwierdzono pojedyncze ziarna pyłku jemioły (Viscum) i bluszczu (Hedera), które według Urbańskiego i Winter (2005) są świadectwem oceanizacji klimatu. Generalnie, gatunki te są uznawane za wskaźniki optimum klimatycznego nie tylko podczas interglacjału eemskiego, gdyż sygnalizują gorące lata i łagodne zimy z wysoką średnią temperatury stycznia (Iversen 1944).

Osady zebrane ze stadionu przy ul. Bułgarskiej były akumulowane później i z uwagi na wysoką zawartość sosny oraz znaczący udział świerka można je łączyć z poziomem 6 „PICEA-ABIES” (Tobolski 1991) lub E6 „PICEA-ABIESALNUS" (Mamakowa 2003).

$\mathrm{Na}$ terenie Poznania grunty organiczne były nawiercone jeszcze w pobliżu ul. Marcelińskiej/ul. Jesiennej i ul. Raszyńskiej (Deja 1969). Żadne z tych stanowisk nie zostało zbadane pod względem flory i fauny. Jednak ze względu na podobieństwo stratygraficzne wykształcenia facjalnego, składu petrograficznego i mechanicznego z profilami Szelaga i Winiar wskazują na pochodzenie eemskie tych gruntów organicznych (Deja 1969).

Profile geologiczne stanowisk interglacjalnych stwierdzonych na terenie miasta Poznań przedstawiono na rycinie 2 . Rysunek powstał na podstawie połączenia danych zestawionych przez Deję (1969) oraz nowych stanowisk badawczych opisanych w niniejszym artykule.

Osady interglacjału eemskiego (pod glinami zlodowacenia bałtyckiego) oprócz miejsc wskazanych w artykule na terenie Poznania (w tym na Głównej) były również udokumentowane w: Swarzędzu, Gortatowie, Kaźmierzu, Mutowie koło Szamotuł oraz między Biedruskiem i Obornikami (Dąbrowski 1999).

\section{PODSUMOWANIE}

Należy zdecydowanie zaznaczyć, że wykonanie omawianych analiz pyłkowych $\mathrm{w}$ żadnym razie nie wyczerpuje zagadnień związanych z problematyką wieków osadów międzyglinowych. Jest to zaledwie kolejny przyczynek do pełnego rozpoznania ich charakteru i wieku, które jednakże jest trudne do wykonania ze względu na zwartą zabudowę miasta. Natomiast, aby w przyszłości możliwe było syntetyczne i podsumowujące opracowanie, konieczne jest sukcesywne zbieranie próbek osadów na wszystkich stanowiskach zwią- 
zanych z zabudową lub przebudową obiektów, gdzie profile geologiczne są dostępne.

Czas akumulacji analizowanych warstw osadów organicznych przypadający na schyłek środkowej części interglacjału eemskiego w świetle uzyskanych wyników wydaje się bezsporny. Świadczy o tym wiele cech wspólnych zaobserwowanych w uzyskanych wynikach przedstawianych w niniejszym opracowaniu oraz w publikacjach dotyczących zmian paleoekologicznych interpretowanych na podstawie badań palinologicznych, zwłaszcza dłuższych sekwencji wykonanych analiz i podsumowań paleośrodowiskowych, na przykład Tobolski (1991), Mamakowa (1988, 1989, 2003). Również zestawienie otrzymanych spektrów z wynikami pojedynczych stanowisk Poznania i okolic (Deja 1969, Środoń 1956; Gołąb, Urbański 1938; Urbański, Winter 2005) potwierdza taką interpretację. Występowanie osadów organicznych wieku eemskiego pomiędzy dwoma poziomami glin morenowych pozwala na korelację z utworami bezpośredniej akumulacji lądolodów zlodowaceń północnopolskich i środkowopolskich z innymi obszarami na terenie i w okolicach Poznania, ustalając ich pozycję litostratygraficzną. Jest to tym łatwiejsze, że - jak wynika z zebranych materiałów, występowanie osadów organogenicznych w utworach międzyglinowych jest dosyć powszechne.

Wyniki wykonanych badań wnoszą również wkład w poznanie warunków paleoekologicznych i przemian środowiskowych w okresie interglacjału eemskiego na terenie środkowej Wielkopolski.

\section{LITERATURA}

Bartkowski T., 1957: Rozwój polodowcowej sieci hydrograficznej w Wielkopolsce Środkowej. Zesz. Nauk. UAM w Poznaniu, Geogr., 8, 1.

Biedrowski Z., 1968: Sandry okolic Poznania. Studium geomorfologiczno-sedymentologiczne. UAM, Poznań [pr. doktorska].

Ciuk E., 1965: Sprawozdanie wstępne z poszukiwań złóż węgla brunatnego w rejonie Moszny. Kwart. Geol., 9.

Ciuk E., 1978: Geologiczne podstawy dla nowego zagtębia węgla brunatnego w strefie rowu tektonicznego Poznań - Czempiń - Gostyń. Przegl. Geol., 10.

Chmal R., 1996: Szczególowa mapa geologiczna Polski arkusz 471-Poznań (N-33-130-D). PIG, Warszawa.

Chmal R., 1997: Objaśnienia do Szczegółowej mapy geologicznej Polski arkusz 471-Poznań (N-33-130-D). PIG, Warszawa.

Dadlez R., 2000: Mapa geologiczna Polski bez utworów kenozoiku w skali 1:1 000 000. PIG. Warszawa.

Dąbrowski S., 1999: Dokumentacja hydrogeologiczna Rejonu Poznańskiego Dorzecza Warty zawierajaca ocenę zasobów dyspozycyjnych wód podziemnych z utworów czwartorzędowych i trzeciorzędowych. Część A. Synteza wyników badań. Hydroconsult Sp. z o.o., Poznań.

Deja W., 1969: Niektóre problemy stratygrafii czwartorzędu na obszarze miasta Poznania. Bad. Fizjogr. nad Pol. Zach., t. XXIII, Ser. A. Geogr. Fiz. 
Gołąb J., Urbański J., 1938: Nowa odkrywka interglacjału na Wymiarach koło Poznania. Roczn. Pol. Tow. Geol., t. 12.

Granoszewski W., 2003: Late Pleistocene vegetation history and climatic changes at Horoszki Duze, E Poland: a palaeobotanical study. Act. Palaeobotanica, Suppl. 4.

Grocholski W., 1991: Budowa geologiczna przedkenozoicznego podloża Wielkopolski. Mat. 62 Zj. PTG, Poznań.

Iversen J., 1944: Viscum, Hedera and Ilex as climate indicators. Geol. Forh. 66(3), 463-483.

Jaskowiak-Schoeneichowa M., 1979: Budowa geologiczna Niecki Szczecińskiej i Bloku Gorzowa. Pr. Inst. Geol., XCVI. Wyd. Geol., Warszawa.

Jastrzębska-Mamełka M., 1985: Interglacjat eemski i wczesny Vistulian w Zgierzu-Rudunkach na Wyżynie Eódzkiej. Act. Geogr. Lodz., 53.

Kondracki J., 1998: Geografia regionalna Polski. Wyd. Nauk. PWN, Warszawa.

Kozarski S., 1995: Deglacjacja pótnocno-zachodniej Polski: warunki środowiska i transformacji geosystemu (-20 ka-10 ka BP). Dok. Geogr., 1.

Mamakowa K., 1988: Pollen stratigraphy of the Eemian and adjoining glacial deposits based on continuous sequences in Poland. Bull. of Polish Acad. of Sc., Earth Sc. 36(3-4).

Mamakowa K., 1989: Late Middle Polish Glaciation, Eemian and Early Vistulian vegetation at Imbramowice near Wroctaw and the pollen stratigraphy of this part of the Pleistocene in Poland. Ac. Palaeobotanica, 29(1).

Mamakowa K., 2003: Plejstocen. [W:] S. Dybova-Jachowicz, A. Sadowska (red.), Palinologia, Wyd. IB PAN, Kraków, 235-266.

Odrzywolska-Bieńskowska E., Kosmowska-Ceranowicz B., Ciuk E., Giel M.D., Grabowska L., Piwocki M., Pożaryska K., Ważyriska H., Ziembińska-Tworzydło M., 1979: Syntetyczny profil stratygraficzny trzeciorzędu polskiej części pótnocno-zachodniego basenu trzeciorzędowego Europy. Przegl. Geol., 9.

Piwocki M., 2002: Ewolucja pogląów na stratygrafię utworów formacji poznańskiej na Niżu Polskim. Przegl. Geol., 50, No. 3.

Środoń A., 1956: W sprawie interglacjału w Szelagu pod Poznaniem. Biul. PIG, 100, Warszawa.

Tobolski K., 1991: Biostratygrafia i paleoekologia interglacjatu eemskiego i zlodowacenia Wisty rejonu konińskiego. [W:] W. Stankowski (red.), Przemiany środowiska geograficznego obszaru Konin - Turek, Wyd. Nauk. UAM, Poznań.

Urbański K., Winter H., 2005: Stanowisko interglacjału eemskiego w Radówku (Pojezierze Łagowskie, zachodnia Polska) i jego implikacje dla litostratygrafii glin zwałowych. Przegl. Geol., 53, No. 5. 